\title{
Isozyme variation in Spanish natural populations of Elytrigia pungens (Pers.) Tutin and $E$. repens (L.) Nevski
}

\author{
CONSUELO SOLER*, CARMEN GALINDO, SONSOLES GONZÁLEZ-CASTAÑO, \\ CARLOS CASANOVA \& PILAR GARCIÁ $\dagger$ \\ Banco de Germoplasma Vegetal, Instituto Nacional de Investigación y Tecnologia Agraria y Alimentaria (INIA), Finca La \\ Canaleja', Apdo. 1045, E28800 Alcalá de Henares (Madrid) and † Servicio de Investigación Agraria, Comunidad \\ Autónoma de Madrid, Finca 'El Encín', Alcalá de Henares (Madrid), Spain
}

\begin{abstract}
Genetic variability in 20 natural populations of the species Elytrigia repens (L.) Nevski and Elytrigia pungens (Pers.) Tutin collected at different geographical places in Spain has been analysed using eight isozyme systems. Analysis of the isoenzymatic patterns indicates inter- and intrapopulational variability in all of the isozyme systems except LAP. The data of intrapopulational variability level, calculated in each population, did not show significant differences in either species. The factorial analysis of correspondence showed a specific distribution of the populations into two groups, based on a series of discriminatory isoenzymatic bands that belonged to different systems and whose relative importance is discussed. The dendrogram obtained with the UPGMA method established a specific distribution for the populational subgroups within each species grouping, and showed a lower level of interpopulational variability in E. repens than in E. pungens. Our results suggest a significant relationship between isozyme variability and several geographical variables (latitude, longitude and altitude).
\end{abstract}

Keywords: E. pungens, E. repens, isozyme variation, geographical distribution.

\section{Introduction}

The tribe Triticeae is made up of nearly 325 species of which more than 75 per cent are perennials; it constitutes an interesting source of genetic resources for the introduction of alien genetic variation into cereals. In recent years much effort has been made on interspecific hybridization between Triticum aestivum and different rhizomatous species of the Triticeae tribe (Mujeeb-Kazi et al., 1987; Sharma \& Baezinger, 1986). This group should be a useful source of genes for adaptative characters, protein genes and others. Studies on genome analysis, cytogenetics, morphology and fertility have been made recently in order to analyse the interspecific relationships between the species of this complex group. However, the genomic affinities and the definition of taxa in many perennial species are unclear and will require more analysis (Jauhar, 1990; Jensen, 1990).

Following Dewey's classification (1984), the genus Elytrigia, with a few exceptions, constitutes the strongly

*Correspondence. rhizomatous, long-anthered and cross-pollinating species traditionally included in Agropyron. However, Melderis (1978) absorbed Elytrigia into Elymus where the caespitoses species were placed in section Caespitosae and the rhizomatous species went into section Elytrigia. We shall concentrate on Elytrigia pungens which grows over most of S.W. Europe (Spain, Portugal and France) and Elytrigia repens, which is a cosmopolitan species with a wide distribution in the Mediterranean climate regions in Asia, Europe, U.S.A. and Canada. E. pungens (octoploid) and E. repens (hexaploid) are complex polyploids whose origin and genomic constitutions are uncertain. The inclusion of E. pungens in Elytrigia is debatable but as Dewey proposes (1984), it would fit better in Elytrigia than in Thinopyrum, the closest related genus.

A preliminary step to optimize the use of genetic resources from wild relative species in cereal crops is to gain knowledge of the extent and distribution of genetic variability. This study examines the extent and patterns of allozyme intra- and interspecific variation in 20 natural populations of $E$. pungens and E. repens from different sites in the Iberian Peninsula. These data 
constitute a first step for characterization planning collection strategies and preservation of this important germplasm. In addition, isozyme studies can provide more information on genetic relationships between $E$. pungens and E. repens.

\section{Materials and methods}

\section{Plant material}

Plants and seeds from 10 populations of Elytrigia repens (L.) Nevski $(2 n=6 \mathrm{x}=42)$ and 10 of Elytrigia

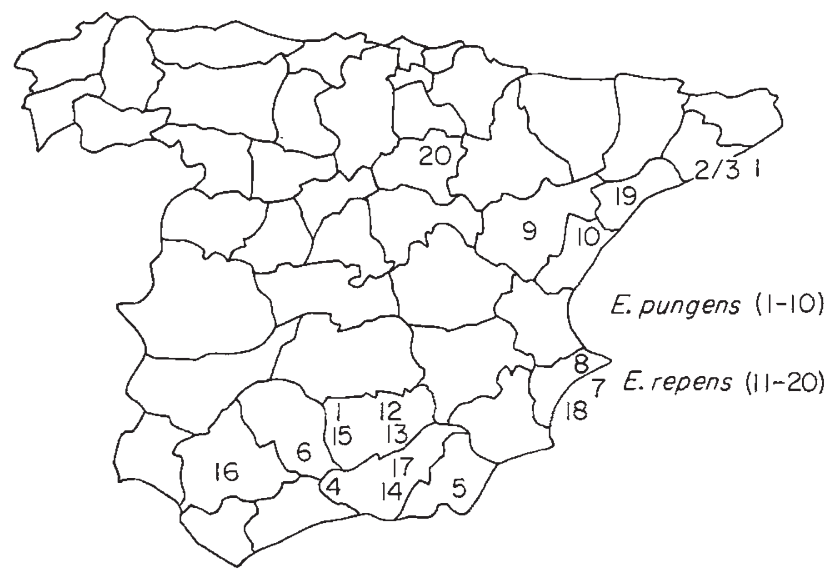

Fig. 1 Diagram of the geographical location of populations included in the present study. pungens (Pers.) Tutin $(2 n=8 \mathrm{x}=56)$ were collected from 18 Spanish localities in 11 provinces of eastern Spain (Fig. 1) during the summer of 1989. Each sample was collected following the method of Hawkes (1980). The plants were taken from different spots each one at least $3 \mathrm{~m}$ away from the others to ensure that individual plants were really separate plants rather than culms from the same plant (both taxa are rhizomatous). Plants were transferred into pots in a greenhouse and screened for their chromosome complement at mitosis (Table 1).

\section{Isozyme analysis}

Biochemical investigations were carried out with 15day-old leaves of 15 plants from each population. The standard cultivar of Triticum aestivum, Chinese Spring, with known isozyme banding patterns was used as control material. Leaf tissue from each individual plant was crushed and immersed in $15 \mu \mathrm{l}$ of distilled and deionized water. The crude extract obtained was soaked up using a paper wick (Whatman $3 \mathrm{MM}$ ) and placed into the gel. Horizontal starch gel (Sigma 10 per cent $\mathrm{w} / \mathrm{v}$ ) electrophoresis was used for analysis of acid phosphatase (ACPH; E.C. 3.1.3.2), cathodal peroxidase (CPX; E.C. 1.11.1.7), esterase (EST; E.C. 3.1.1.1), leucine aminopeptidase (LAP; E.C. 3.4.11.1), malate dehydrogenase (MDH; E.C. 1.1.1.37), phosphoglucoisomerase (PGI; E.C. 5.3.1.9) and phosphoglucomutase (PGM; E.C. 2.7.5.1). Aspartate amino-

Table 1 Geographical location of E. pungens and E. repens populations

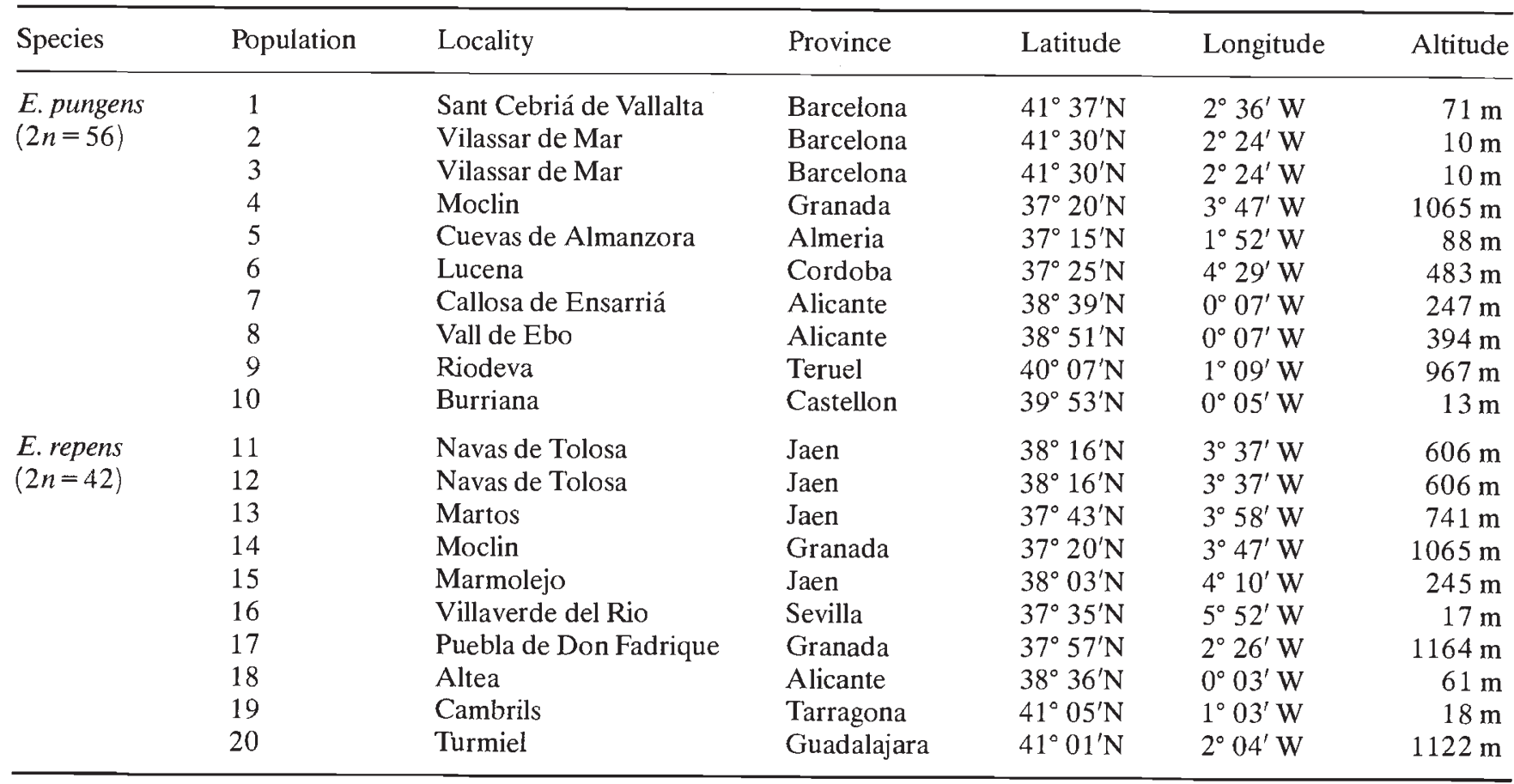


transferase (AAT; E.C. 2.6.1.1) isozymes were separated using horizontal polyacrylamide gels ( 8 per cent $\mathrm{w} / \mathrm{v})$.

For the analysis of the ACPH, CPX and MDH systems, gels were run at $175 \mathrm{~V}$ for $5 \mathrm{~h}$ with $0.005 \mathrm{M}$ histidine- $\mathrm{HCl}$ acid $p \mathrm{H} 7.0$ gel buffer and $0.043 \mathrm{M}$ triscitric acid $p \mathrm{H} 7.0$ electrode buffer. Electrophoresis conditions for the rest of the enzymatic systems consisted of $270 \mathrm{~V}$ for $3 \mathrm{~h}$ with $0.015 \mathrm{M}$ tris-citric acid $p \mathrm{H}$ 7.75 gel buffer and $0.01 \mathrm{M} \mathrm{NaOH}$-boric acid $p \mathrm{H}$ 8.6 electrode buffer. Enzyme staining methods were as reported by Shaw \& Koën (1968) and Brewer \& Sing (1970).

The relative mobility of each band was estimated in each system. The bands were numbered on the basis of their relative position in the gel. Statistical methods took into account the presence or absence of each band as a differential feature. A total of 92 different isozyme bands was considered for the statistical comparisons.

To analyse interpopulation variability, the NTSYS statistical package was used (Rohlf, 1987). Data were presented in the form of numbers of individuals exhibiting each scored band in each population as suggested by Buth (1984). The data matrix was subjected to factorial correspondance analysis (FCA) (Benzecri \& Benzecri, 1980; Lebart et al., 1984), being an accurate method for this kind of data according to Asins \& Carbonell (1986b). This analysis could be considered as a weighted principal component analysis of a contingency table, the result being independent from the original codification of the data. Assuming the total variance (100 per cent) represented by 19 factorial axes, this statistical method provides two data matrices; first, the coordinate values of each population projec- tion on the factorial axes and second, the contribution of each band to the variance of each factorial axis. Product-moment correlation coefficients of Pearson were calculated from the first data matrix, to analyse interpopulational similarity; thus the distances are constrained within the range \pm 1 , and may produce more effective dendrograms if a few of the objects are very dissimilar from the others. This similarity matrix was submitted to UPGMA cluster method (unweighted pairgroups method which uses arithmetic averages)(Sneath \& Sokal, 1973) to produce a dendrogram.

Intrapopulational variability was estimated calculating the fraction of variance in each population analysed in relation to the contribution of each band in each population to the total variance represented by the factorial axes.

To assess possible association between isozyme variability and geographical variables (latitude, longitude and altitude), Spearman's rank correlation was performed using SYSTAT (Solbring, 1985) statistical package (Table 1).

\section{Results}

Remarkable interspecific differences between isozyme phenotypes for ACPH, AAT, MDH, PGI and PGM were found among the species and between the species and the standard wheat Chinese Spring (Fig. 2). Three zones, with different migration rates were found in AAT and EST. They were designated AATI, AATII, AATIII and ESTI, ESTII, ESTIII, respectively, according to their relative mobility. The phenotypes of the MDH system showed two regions, MDHI and MDHII, in all the materials. The LAP phenotype exhibited only one band which was monomorphic within and between

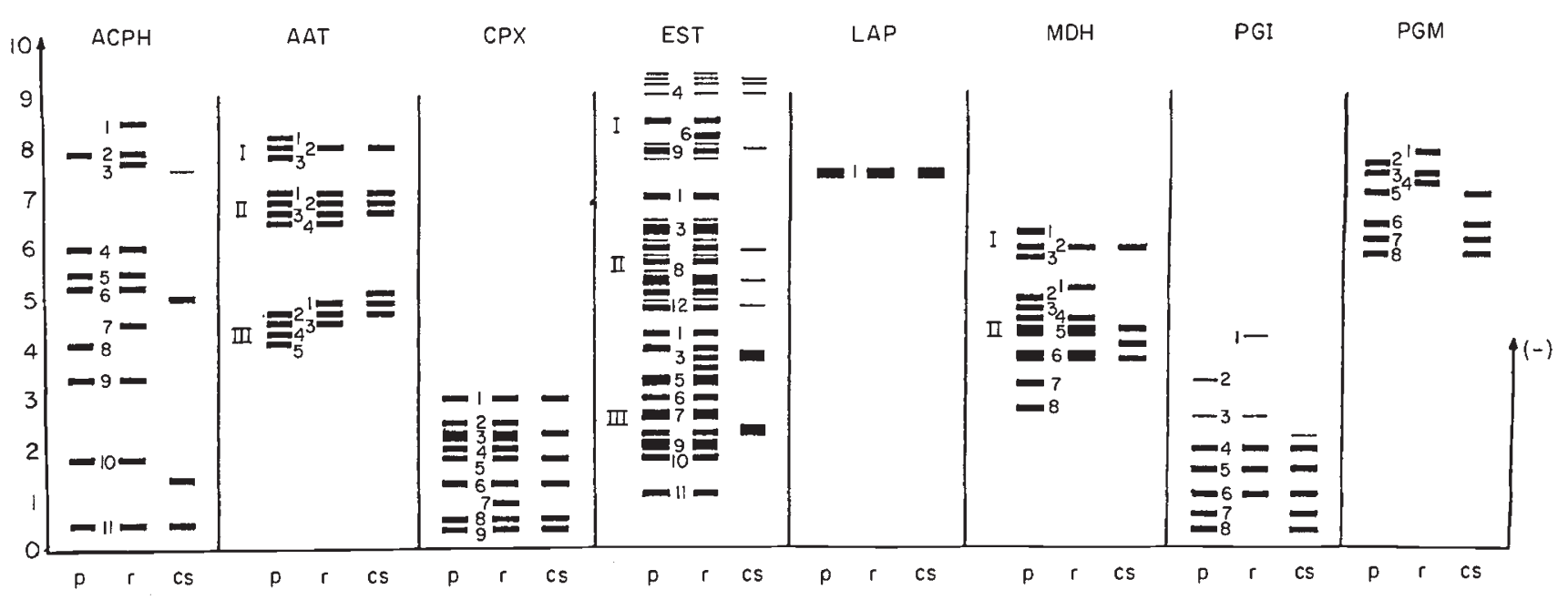

Fig. 2 Electrophoretic mobility bands for isozyme systems analysed in E. pungens (p), E. repens $(\mathrm{r})$ and T. aestivum cv. Chinese Spring (cs). 
the populations and species. The phenotypes and migration rates for all these systems were similar to that shown by the common wheat, Chinese Spring, used as control in each gel, and previously described by other authors (Hart, 1975; Jaaska, 1980; Benito \& Salinas, 1983; McIntyre, 1988).

Asins and Carbonell (1986a) considered a population non-uniform when at least one band and/or pattern was found different in at least one plant. According to this assumption, the percentage of nonuniform populations in E. pungens and E. repens was 100 per cent, because the 20 populations showed polymorphism in at least one isozyme system. The intrapopulational polymorphism was remarkably high for EST, but LAP was monomorphic in both species, and PGM and PGI were monomorphic in E. repens. In this study, intrapopulational variability is expressed by the fraction of variance calculated in each population as previously described. The values ranged in $E$. pungens populations from 0.036 to 0.089 with a mean value of 0.062 ; and from 0.039 to 0.089 with a mean value of 0.056 in E. repens populations. There were no significant differences between the means, when they were estimated according to $F$-Snedecor test $(F=1.117)$.

An analysis of correspondence should provide evidence of the extent of interpopulation distances. Thus, the populations projection for the three first factorial axes (44.6 of variance) showed considerable divergence between two groups of populations (Fig. 3). Each group consisted of all the populations from each species (1-10 for E. pungens and 11-20 for E. repens). The UPGMA grouping method revealed further evidence that they were separable into two groups, and again showed remarkable interspecific dichotomy. The dendrogram also showed a lower level of genetic differentiation in the E. repens group (below in Fig. 4) than in the E. pungens group (above).

The factorial correspondence analysis provides a data matrix with the contribution of each variable (isozymatic band) to the variance of the different factorial axes. Table 2 summarizes the isozymatic bands with a higher and a lower contribution to the variance of the first five axes. The bands LAP-1 (monomorphic), ACPH-9, ESTI-4, MDHIII-5, PGI-4, PGI-5, PGI-6 and PGM-3, which were fixed in all the

Table 2 Number of isozymatic bands with a higher (above) and a lower (below) contribution to the variance of the first five factorial axes

\begin{tabular}{|c|c|c|c|c|c|c|c|c|c|}
\hline \multicolumn{2}{|c|}{1} & \multicolumn{2}{|c|}{2} & \multicolumn{2}{|c|}{3} & \multicolumn{2}{|c|}{4} & \multicolumn{2}{|c|}{5} \\
\hline PGM-7 & 0.025 & AATIII-3 & 0.027 & PGM-8 & 0.027 & ESTII-10 & 0.034 & CPX-5 & 0.025 \\
\hline ACPH-6 & 0.028 & PGI-8 & 0.029 & MDHII-2 & 0.027 & AATII-4 & 0.034 & CPX-3 & 0.028 \\
\hline MDHII-7 & 0.028 & ESTIII-5 & 0.032 & PGI-1 & 0.031 & ESTI-7 & 0.040 & PGM-6 & 0.031 \\
\hline ACPH-1 & 0.029 & ESTII-6 & 0.036 & AATIII-1 & 0.031 & ACPH-4 & 0.045 & ESTII-4 & 0.033 \\
\hline ESTI-6 & 0.029 & MDHII-2 & 0.047 & ESTII-12 & 0.038 & ESTIII-8 & 0.051 & ESTIII-2 & 0.033 \\
\hline PGI-8 & 0.030 & PGM-8 & 0.047 & CPX-4 & 0.039 & ESTIII-1 & 0.061 & ESTIII-5 & 0.034 \\
\hline PGM-5 & 0.032 & ESTIII-11 & 0.049 & ESTIII-4 & 0.056 & PGM-2 & 0.072 & ESTIII-10 & 0.039 \\
\hline MDHII-3 & 0.032 & ESTIII-8 & 0.054 & ESTIII-2 & 0.058 & ESTII-2 & 0.073 & ESTI-7 & 0.045 \\
\hline AATIII-1 & 0.032 & ESTIII-3 & 0.060 & АCPH-11 & 0.063 & PGM-8 & 0.076 & AATI-1 & 0.055 \\
\hline PGI-7 & 0.035 & ESTII-2 & 0.077 & ACPH-1 & 0.074 & MDHII-2 & 0.076 & AATI-3 & 0.055 \\
\hline ESTIII-4 & 0.036 & ESTI-1 & 0.084 & ACPH-6 & 0.083 & & & ACPH-7 & 0.089 \\
\hline MDHII-7 & 0.039 & ESTII-1 & 0.089 & & & & & & \\
\hline PGI-1 & 0.040 & & & & & & & & \\
\hline MDHII-4 & 0.044 & & & & & & & & \\
\hline MDHII-1 & 0.044 & & & & & & & & \\
\hline PGM-1 & 0.056 & & & & & & & & \\
\hline PGM-4 & 0.056 & & & & & & & & \\
\hline LAP-1 & 0.0008 & LAP-1 & 0.0003 & LAP-1 & 0.0005 & LAP-1 & 0.0002 & LAP-1 & 0.0002 \\
\hline PGI-4 & 0.0008 & PGI-4 & 0.0003 & PGI-4 & 0.0005 & PGI-4 & 0.0002 & PGI-4 & 0.0002 \\
\hline PGI-5 & 0.0008 & PGI-5 & 0.0003 & PGI-5 & 0.0005 & PGI-5 & 0.0002 & PGI-5 & 0.0002 \\
\hline PGI-6 & 0.0008 & PGI-6 & 0.0003 & PGI-6 & 0.0005 & PGI-6 & 0.0002 & PGI-6 & 0.0002 \\
\hline PGM-3 & 0.0008 & PGM-3 & 0.0003 & PGM-3 & 0.0005 & PGM-3 & 0.0002 & PGM-3 & 0.0002 \\
\hline ACPH-10 & 0.0008 & ACPH-10 & 0.0003 & ACPH-10 & 0.0005 & ACPH-10 & 0.0002 & ACPH-10 & 0.0002 \\
\hline MDHII-5 & 0.0008 & MDHII-5 & 0.0003 & MDHII-5 & 0.0005 & MDHII-5 & 0.0002 & MDHII-5 & 0.0002 \\
\hline ESTI-4 & 0.0008 & ESTI-4 & 0.0003 & ESTI-4 & 0.0005 & ESTI-4 & 0.0002 & ESTI-4 & 0.0002 \\
\hline
\end{tabular}




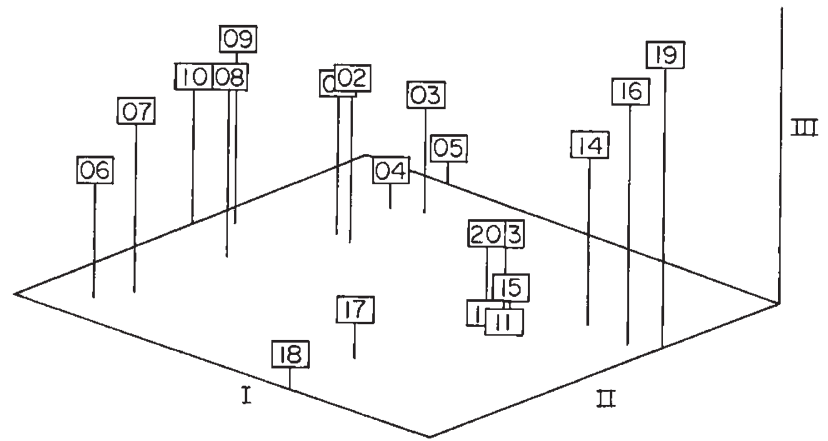

Fig. 3 Projection of each population on the first three factorial axes.

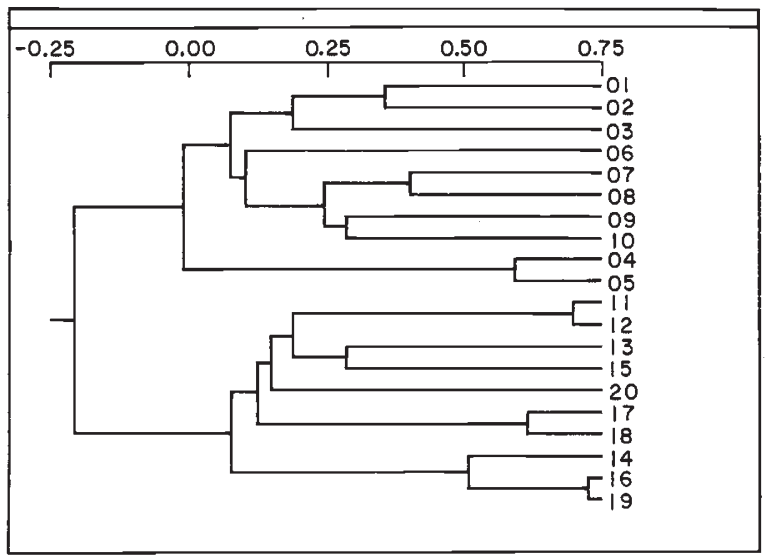

Fig. 4 Population UPGMA dendrogram based on correlation coefficient as distance index.

materials, contributed the least to the total variance in all the axes. On the other hand, bands AATIII-1, ESTIII-4, MDHII-1, PGI-1, PGM-1 and PGM-4 specifically found in E. repens, and MDHII-3, MDHII7, MDHII-8, PGI-2, PGI-7, PGI-8 and PGM-5 that specifically belonged to $E$. pungens, showed the highest contribution to the variance of the first factorial axis (the one that marks an interspecific dichotomy). The most distinctive systems in relation to isozyme difference between $E$. pungens and $E$. repens, were $\mathrm{MDH}$, PGM and PGI. Some bands of these systems contributed more than the others to the variance of the first factorial axis in the analysis of correspondence. We think that the following bands have taxonomical value and can be used to distinguish the species: (i) E. repens: AATIII-1, MDHII-1, PGI-1, PGM-1 and PGM-4; (ii) E. pungens: MDHII-3, MDHII-7, MDHII-8, PGI-2, PGI-7, PGI-8 and PGM-5.

Spearman's rank correlation index was calculated between all variables (frequency of each band, geographical variables and variability in each population). Results are listed in Table $3 \mathrm{a}$ (E. pungens
Table 3 Summary of Spearman's rank correlation coefficients in $E$. pungens (a) and E. repens (b) populations, between isozymatic bands, geographical variables: latitude, longitude and altitude, and intrapopulational variability. Only those that were significant have been listed. Significance: ${ }^{*}=0.05>P>0.01 ; \nmid 0.01>P>0.005$; $\neq 0.005>P$

\begin{tabular}{|c|c|c|c|c|}
\hline a & Latitude & Longitude & Altitude & Variability \\
\hline AI1 & -0.001 & $-0.858 \ddagger$ & 0.214 & 0.000 \\
\hline $\mathrm{AI} 2$ & 0.316 & $0.724 \dagger$ & -0.338 & -0.360 \\
\hline AI3 & -0.001 & $-0.858 \pm$ & 0.214 & 0.000 \\
\hline AII4 & 0.340 & -0.286 & -0.189 & $-0.733 \dagger$ \\
\hline AII3 & -0.038 & $-0.573^{*}$ & 0.419 & -0.190 \\
\hline PI3 & -0.414 & -0.231 & $0.585^{*}$ & -0.203 \\
\hline PI7 & $-0.808 \ddagger$ & -0.360 & $0.672 \dagger$ & 0.455 \\
\hline PM2 & $-0.679 \dagger$ & 0.162 & 0.437 & $0.730 \ddagger$ \\
\hline PM6 & 0.368 & $0.712 \dagger$ & 0.171 & 0.203 \\
\hline PM7 & -0.010 & $0.728 \uparrow$ & 0.182 & 0.315 \\
\hline PM8 & $-0.698 \dagger$ & 0.263 & 0.349 & 0.087 \\
\hline CP1 & -0.079 & $0.726 \dagger$ & -0.249 & 0.019 \\
\hline $\mathrm{CP} 2$ & $0.900 \ddagger$ & -0.114 & -0.428 & -0.427 \\
\hline $\mathrm{CP} 3$ & $-0.723 \ddagger$ & -0.338 & 0.240 & 0.006 \\
\hline $\mathrm{CP} 4$ & $0.947 \ddagger$ & -0.142 & -0.480 & -0.277 \\
\hline CP5 & $-0.733 \dagger$ & -0.338 & 0.240 & 0.005 \\
\hline CP6 & 0.474 & $0.556^{*}$ & -0.240 & 0.227 \\
\hline MDI2 & $0.585 \dagger$ & -0.435 & -0.151 & -0.177 \\
\hline MDII2 & $-0.698 \dagger$ & 0.263 & 0.349 & 0.087 \\
\hline MDII8 & 0.122 & -0.143 & -0.045 & $-0.638 \dagger$ \\
\hline EI7 & 0.445 & -0.297 & $-0.619 \dagger$ & -0.222 \\
\hline EII10 & $0.651 \dagger$ & 0.128 & -0.187 & 0.157 \\
\hline EIII2 & -0.217 & 0.218 & $0.703 \dagger$ & 0.225 \\
\hline EIII7 & -0.069 & $-0.666 \dagger$ & -0.200 & -0.112 \\
\hline Altitude & $-0.585^{*}$ & 0.190 & 1.000 & 0.310 \\
\hline b & Latitude & Longitude & Altitude & Variability \\
\hline AII2 & 0.127 & -0.292 & $0.576^{*}$ & $-0.679 \dagger$ \\
\hline AII4 & 0.096 & -0.144 & $0.584^{*}$ & $-0.679^{*}$ \\
\hline AIII3 & 0.105 & -0.105 & -0.524 & $0.731 \dagger$ \\
\hline CP1 & -0.253 & 0.253 & $0.590^{*}$ & $-0.705 \dagger$ \\
\hline CP3 & -0.093 & $0.599^{*}$ & -0.136 & 0.289 \\
\hline CP7 & $0.698 \dagger$ & -0.524 & 0.000 & 0.348 \\
\hline AC6 & -0.156 & -0.017 & $0.685 \dagger$ & $-0.701 \uparrow$ \\
\hline $\mathrm{AC} 7$ & 0.017 & 0.156 & $-0.703 \dagger$ & $0.683 \dagger$ \\
\hline MDI2 & $-0.574^{*}$ & 0.446 & -0.306 & 0.070 \\
\hline EI1 & 0.316 & $-0.601^{*}$ & 0.511 & -0.075 \\
\hline EI2 & -0.316 & $0.601^{*}$ & -0.511 & 0.075 \\
\hline EII5 & $0.615^{*}$ & -0.238 & -0.270 & 0.156 \\
\hline EII12 & 0.007 & 0.142 & -0.471 & $0.649 \dagger$ \\
\hline EIII1 & 0.123 & 0.103 & -0.377 & $0.642 \dagger$ \\
\hline EIII6 & $0.562 *$ & -0.431 & -0.336 & -0.239 \\
\hline EIII8 & $0.688 \dagger$ & $-0.660 \dagger$ & -0.495 & 0.123 \\
\hline Latitude & 1.000 & $-0.780 \ddagger$ & -0.183 & 0.225 \\
\hline Altitude & -0.183 & -0.122 & 1.000 & $-0.675 \dagger$ \\
\hline
\end{tabular}


populations) and $3 \mathrm{~b}$ (E. repens populations) and show $r$ values and the level of significance. Populations of $E$. pungens revealed a higher number of isozyme bands associated with geographical variables than E. repens populations, showing positive correlation values. On the other hand, correlation between variability and altitude was negative and highly significant in E. repens.

\section{Discussion}

The species E. pungens and E. repens are considered segmental autoallopolyploids and their genome constitution and evolutionary origin have not yet been established. Dewey (1976) assigned the genome formula $S_{l} S_{l} S_{2} S_{2} X X$ to $E$. repens; the $S$ genomes seem to originate from the genus Pseudoroegneria, while the origin of the $X$ genome is unknown. More recently, Mujeeb-Kazi et al. (1989) proposed the genome formula $E_{1} E_{1} E_{2} E_{2} Z Z$, in which the $E$ genomes would come from Thinopyrum elongatum and $Z$ is not well determined. Moreover, it has been proposed that $E$. repens belongs to other genera: Elytrigia or Agropyron (Dewey, 1984; Love, 1984). Cauderon (1958) assigned the genome formula $K_{1} K_{1} K_{2} K_{2} E_{4} E_{4} E_{5} E_{5}$ to $E$. pungens, and proposed that the origin of the $E$ genomes was in Th. elongatum. The inclusion of $E$. pungens in the genera Thinopyrum and Elytrigia has also been discussed by different authors (Dewey, 1984; Love, 1984).

The intergenomic relationships can perhaps be explained by the analysis of the meiotic behaviour of the interspecific hybrids. However, hybrids are difficult to obtain and, in any case, an isozymic analysis can give complementary information on interspecific biochemical and genetic affinities (Brody \& Mendlinger, 1980; McIntyre, 1988). Thus, the wild species studied here presented a considerable number of common bands and even complete electrophoretic patterns on the isozyme systems analysed. This result suggests a strong evolutionary affinity and the possibility that they share some important parts of their genomes.

The differences between the isozyme patterns of the wild species and that of the common wheat T. aestivum cv Chinese Spring were more remarkable. This should be important in detecting the introgression of alien genes from Elytrigia species into wheat obtained by crossing.

Previous studies on genetic variability carried out in the Triticeae served to demonstrate that allogamous species present more intra- and interpopulational polymorphism than the autogamous species (Brown et al., 1978a, b; Brody \& Mendlinger, 1980; Nevo et al., 1982; Asins \& Carbonell, 1986a, b). The variability in the wild populations studied here is higher than that found in different diploid and tetraploid species of the genus Triticum (autogamous and annuals) previously reported by Asins \& Carbonell (1986a) and wild diploid wheats Triticum monococcum and T. urartu (Smith-Huerta et al., 1989).

Nevo (1978) concluded that populations or species with a wide distribution are relatively more polymorphic and heterozygous than habitat restricted species, but our data did not show significant differences on intrapopulational variability levels of $E$. repens (with an extensive natural distribution) and $E$. pungens (with a restricted habitat).

The lower interpopulational variability observed within the group of E. repens than in E. pungens indicates the high adaptative flexibility of the latter, and could be explained from the viewpoint of its relatively relaxed requirements of ecogeographical adaptations. Asins \& Carbonell (1986a) reported a similar case in the relationship between the interpopulational variability and the environmental distribution in wild species of Triticum, in which the more widely distributed species such as $T$. tauschii and $T$. monococcum boeoticum, were more variable than the species $T$. bicorne, $T$. sharonensis and $T$. longissimum, which had a restricted geographical range.

The cluster of populations within E. pungens (Fig. 4) shows a subdivision into three or four groups. An examination of correlation data between different isozymatic bands and geographical variables reveals a negative and highly significant correlation between latitude and bands PGM-8 and MDHII-2. These isozymatic bands are characteristic of populations 04 and 05 which group closely together in the dendrogram, and were collected in two proximal sites in the south of Spain (low latitude). In addition, correlation coefficients were positive and highly significant between latitude and bands CPX-2 and CPX-4, that are present in all populations (with frequency value $=1$ ) except in populations 04,05 and 06 which are from the south of Spain.

The band PGI-7, negative and highly significant correlated with latitude, has a frequency value $=1$ in all $E$. pungens populations except in 01,02 and 03. These geographically close populations, collected in the north-eastern part of the country, cluster together in the dendrogram.

Within the cluster, populations $07,08,09$ and 10 from eastern sites (low longitude), form a subgroup. Distinctive isozymatic bands AATII- 1 and AATII-3 of these populations showed negative and highly significant values with longitude.

Considering $E$. repens populations, results show a low number of significant correlations between band 
frequencies and geographical variables, latitude and longitude. As a feature there is a negative correlation between variability and latitude, exhibiting more variability in the populations collected at low latitude. In this way, band ACPH-7 characteristic of populations 16 and 19 showed a negative and significant correlation value with altitude. Together with 14 these populations form a group in the dendrogram. This result can be explained, perhaps, because the three populations were collected from dump soils and swampy zones and all of them present a specific ACPH-1 band.

The results reported here suggest a significant relationship between isozymatic variability and geographical variables: latitude, longitude and altitude, these associations being more remarkable for latitude and longitude in $E$. pungens and for altitude in E. repens. Different authors have previously reported associations between isozymatic variability and different environmental factors, such as geographical location, soil types, water availability, etc., in different species (Nevo et al., 1982, 1988a, b, 1991; Konishi \& Matsuara, 1991).

To improve methods to obtain a wider diversity of genotypes for germplasm collection, information of inter- and intrapopulational analysis of $E$. pungens and E. repens can contribute in maximizing sampling strategies and preservation of these wild species (Marshall \& Brown, 1975).

\section{Acknowledgements}

The authors thank Mr Juan Ruiz for collecting plant material, Professor Nicolás Jouve for preparation of the manuscript. This study was funded by I.N.I.A. grant number 7689 .

\section{References}

ASINS, M. J. AND CARBONELl, E. A. 1986a. A comparative study on variability and phylogeny of Triticum species. I. Intraspecific variability. Theor. Appl. Genet., 72, 551-558.

ASINS, M. J. AND CARBONELL, E. A. 1986b. A comparative study on variability and phylogeny of Triticum species. II. Interspecific relationships. Theor. Appl. Genet., 72, 559-568.

BENITO, C. AND SALINAS, J. 1983. The chromosomal location of malate dehydrogenase isozymes in hexaploid wheat (Triticum aestivum L.). Theor. Appl. Genet., 64, 255-258.

BENZECRI, J. P. AND BENZECRI, F. 1980. Practique de l'analyse des donées. Dunod, Paris.

BREWER, G. J. AND SING, C. F. 1970. An Introduction to Enzyme Techniques. Academic Press, New York.

BRODY, T. AND MENDLINGER, S. 1980. Species relationships and genetic variation in diploid wheats (Triticum, Aegilops) as revealed by starch gel electrophoresis. Pl. Syst. Evol., 136, 247-258.
BROWN, A. H. D., ZOHARY, D. AND DAGAN, O. 1978a. Genetic variation in natural populations of wild barley (Hordeum spontaneum). Genetica, 49, 97-108.

BROWN, A. H. D., ZOHARY, D. AND NEVO, E. 1978b. Outcrossing rates and heterozygosity in natural populations of Hordeum spontaneum Koch in Israel. Evolution, 33, 815-833.

BUTH, D. G. 1984. The application of electrophoretic data in systematic studies. Ann. Rev. Ecol. Syst., 15, 501-522.

CAUDERON, Y. 1958. Etude citogénetique des Agropyron francais et de leurs hybrids avec les blés. Ann. Amelior. Pl., 58, 389-567.

DEWEY, D. R. 1976. Derivation of a new forage grass from Agropyron repens $\times$ Agropyron spicatum hybrids. Crop Sci., 16, 175-180.

DEWEY, D. R. 1984. The genomic system of classification as a guide to the intergeneric hybridization with the perennial Triticeae. In: Gustafson, J. P. (ed.), Gene Manipulation in Plant Improvement, 16th Stadler Genetics Symposium, Plenum Press, New York.

HART, G. E. 1975. Glutamate oxalacetate transaminase isozymes of Triticum: evidence for multiple systems of triplicate structural genes in hexaploid wheat. In: Market, C. L. (ed.) Developmental Biology, Isozymes III, Academic Press, New York.

HAWkes, J. G. 1980. Crop Genetic Resources. Field Collection Manual for Seed Crops, Root and Tuber Crops, Tree Fruit Crops and Related Wild Species. Edited by International Board for Plant Genetic Resources and the European Association for Research on Plant Breeding (EUCARPIA), Rome.

JAASKA, v. 1980. Electrophoretic survey of seedling esterases in wheats in relation to their phylogeny. Theor. Appl. Genet., 56, 273-284.

JAUHAR, P. P. 1990. Multidisciplinary approach to genome analysis in the diploid species Thinopyrum bessarabicum and Th. elongatum (Lophopyrum elongatum), of the Triticeae. Theor. Appl. Genet., 80, 523-536.

JENSEN, K. B. 1990. Cytology, and morphology of Elymus kengii (Keng) Tzvelev and E. glandiglumis (Keng) A. Love (Triticeae: Poaceae). Genome, 33, 563-570.

KONISHI, T. AND MATSAURA, s. 1991. Geographic differentiation in isozyme genotypes of Himalayan barley (Hordeum vulgare). Genome, 34, 704-709.

LEBART, A., MORINEAU, A., WARWICK, A. 1984. Multivariate Statistical Descriptive Analysis. Wiley, New York.

Love, A. 1984. Conspectus of the Triticeae. Feddes Report, 95, 425-521.

MCINTYRE, C. L. 1988. Variation at isozyme loci in Triticeae. $P l$. Syst. Evol., 160, 123-142.

MARSHALL, D. R. AND BROWN, A. H. D. 1975. Optimum sampling strategies in genetic conservation. In: Frankel, O. H. and Hawks, J. G. (eds), Crop Genetic Resources Today and Tomorrow, Cambridge University Press, Cambridge, pp. 53-80.

MELDERIS, A. 1978. Taxonomic notes on the tribe Triticeae (Gramineae), with special reference to the genera Elymus L. sensu lato, and Agropyron (Gaertner) sensu lato. Linn. Soc. Bot., 76, 369-384. 
MUJEEB-KAZI, A., ROLDAN, A., SUH, D. Y., SITCH, L. A. AND FAROOQ, S. 1987. Production and cytogenetics of Triticum aestivum hybrids with some caespitose Agropyron species. Genome, 29, 537-553.

MUJEEB-KAZI, A., ROLDAN, S., SUH, D. Y., TER-KUILE, N. AND FAROOQ, S. 1989. Production and cytogenetics of Triticum aestivum L. Hybrids with some rhizomatous Agropyron species. Theor. Appl. Genet., 77, 162-168.

NEvo, E. 1978. Genetic variation in natural populations: patterns and theory. Theor. Popul. Biol., 13, 121-177.

NEVo, E., BEILES, A. AND KRUGMAN, T. 1988a. Natural selection of allozyme polymorphisms. II. A microgeographic climatic differentiation in wild emmer wheat Triticum dicoccoides. Theor. Appl. Genet., 75, 529-538.

NEVO, E., BEILES, A. AND KRUGMAN, T. 1988b. Natural selection of allozyme polymorphisms. A microgeographic differentiation by edaphic, topographical and temporal factors in wild emmer wheat, Triticum dicoccoides. Theor. Appl. Genet., 76, 737-752.

NEVO, E., GERECHTER-AMITAI, Z. AND BEILES, A. 1991. Resistance of wild emmer wheat to stem rust: ecological, pathological and allozyme associations. Euphytica, 53, 121-130.

NEVo, E., GolenberG, E., BEILES, A. AND BROWN, A. H. D. 1982.
Genetic diversity and environmental association of wild wheat, Triticum dicoccoides, in Israel. Theor. Appl. Genet., 62, 241-254.

ROHLF, J. F. 1987. NTSYS. pc: numerical taxonomy and multivariate analysis system for the IBM PC microcomputer (and compatibles). In: Setavek, N. Y. (ed.), Applied Biostatistics, INC.

SHARMA, H. C. AND BAEZINGER, P. S. 1986. Production, morphology, and cytogenetic analysis of Elymus caninus (Agropyron caninum) $\times$ Triticum aestivum $\mathrm{F}_{1}$ hybrids and backcross-1 derivatives. Theor. Appl. Genet., 71, $750-756$.

SHAW, C. R. AND KOEN, A. L. 1968. Starch gel electrophoresis of isozymes. In: Smith, I. (ed.), Chromatographic and Electrophoretical Techniques, Interscience, New York.

SMITH-HUERTA, N. L., HUERTA, A. J., BARNHART, D. AND WAINES, J. G. 1989. Genetic diversity in wild diploid wheats Triticum monococcum var. boeoticum and T. urartu (Poaceae). Theor. Appl. Genet., 78, 260-264.

SNEATH, P. H. A. AND SOKAL, R. R. 1973. Numerical Taxonomy. Freeman, San Francisco.

SOLBRING, o. 1985. SYSTAT, Inc. Version 3.0. Harvard University, Cambridge, U.S.A. 